\title{
Heavy-mineral analysis in Polish investigations of Quaternary deposits: a review
}

\author{
Bogusław Marcinkowski ${ }^{1}$, Elżbieta Mycielska-Dowgiałło* \\ ${ }^{1}$ Polish Geological Institute - National Research Institute, Rakowiecka 4, 00-975, Warsaw, Poland; \\ e-mail: boguslaw.marcinkowski@pgi.gov.pl \\ ${ }^{2}$ Family Alliance School of Higher Education, M. Grzegorzewskiej 10, 02-778, Warsaw, Poland; \\ e-mail: mycdow@wp.pl \\ * corresponding author
}

\begin{abstract}
The composition of heavy-mineral assemblages is one of the main textural features of sediments because they can have significant value for the interpretation of, among others, their depositional environment, their depositional processes, and their stratigraphic position. Distinctive features of heavy minerals include their resistance to chemical weathering and mechanical abrasion, their habit, and their density. These parameters are the most widely used in the heavy-mineral research of Quaternary deposits in Poland, as well as in such research in other countries conducted by Polish scientists. Several other heavy-mineral parameters can also be used in various types of interpretation. It is discussed whether heavy-mineral analysis is decisive in the evaluation of deposits or whether it plays mainly a role that may support evidence obtained by other types of analysis. The attention is mainly devoted to transparent heavy minerals; the significance of opaque heavy minerals for interpretational purposes is only mentioned.
\end{abstract}

Key words: heavy-mineral analysis, heavy-mineral resistance, heavy-mineral habit, heavy-mineral density, Poland

\section{Introduction}

The composition of heavy-mineral assemblages is a main textural feature of sediments, just like the grain-size distribution (Mycielska-Dowgiałło \& Ludwikowska-Kędzia, 2011; Woronko et al., 2012), rounding and surface morphology of quartz grains in sand and silt (Mycielska-Dowgiałło \& Woronko, 2004) and the petrographical composition of the light minerals (Mycielska-Dowgiałło, 1995, 2007; Woronko, 2013). The best method for determining the source material of sediments under study, as well as the environment and dynamics of their transport and deposition, is joint analysis of all these textural features (cf. Morton et al., 2013; Wachecka-Kotkowska \& Lu-
dwikowska-Kędzia, 2013). Each of them provides its own information, which supplements the other data.

The aim of the present contribution is to sum up the results of investigations conducted in Poland and in other countries by Polish scientists, which used heavy-mineral analysis of Quaternary deposits to determine their origin, age, stratigraphical position, depositional environment and post-depositional changes.

In lithological and stratigraphical investigations of Quaternary fine-grained deposits, Polish researchers commonly use heavy minerals for the determination of local changes in the way of transport (see Weckwerth \& Chabowski, 2013), the depositional processes and the depositional environment (see, for in- 
stance, Ludwikowska-Kędzia, 2013). However, they can also be used, together with other, complex lithological, geochemical, and petrographical techniques, in lithostratigraphical studies with a wider scope, which address large areas of clastic rocks. Heavy-mineral analyses then support and supplement the determination of the stratigraphical position of the deposits under study, their origin, direction of transport or geological boundaries. It appears that heavy minerals can even help to unravel the tectonic-structural conditions present during and after sedimentation (Derkachev \& Nikolaeva, 2013).

\subsection{Polish heavy-mineral research}

The analysis of heavy-mineral assemblages for sedimentological investigations of Quaternary sediments was introduced in Poland at a larger scale in the middle of the $20^{\text {th }}$ century (Łydka, 1953; Gadomska, 1959; Kosmowska-Ceranowicz, 1966; Łydka \& Turnau-Morawska, 1967; Morawski, 1968). The interpretation potential of heavy minerals has been gradually widened, based on specific properties. The ones most widely used by Polish researchers in Poland and elsewhere concern mostly transparent heavy minerals and can be shortly described as follows.

(1) Different resistance to chemical weathering and mechanical abrasion (Morawski, 1968; Krysowska-Iwaszkiewicz, 1974; Rzechowski et al.,1975; Florek et al., 1987; Mycielska-Dowgiałło, 1995, 2007; Barczuk \& Mycielska-Dowgiałło, 2001; Ludwikowska-Kędzia, 2013; Wachecka-Kotkowska \& Ludwikowska-Kędzia, 2013; Weckwerth \& Chabowski, 2013; Woronko et al., 2013) owing to which, among other things, the degree of weathering may be recognised (in soils and lithological profiles) (Racinowski \& Rzechowski, 1969; Konecka-Betley \& Majsterkiewicz, 1973; Kuźnicki et al., 1974; Kamińska et al., 1986; Cichosz-Kostecka et al., 1991; Dzierwa \& Mycielska-Dowgiałło, 2003; Barczuk \& Nejbert, 2007; Roman, 2010).

(2) Different habits of heavy-mineral grains, which are important during grain selection in fluvial, aeolian and shore processes (Racinow- ski, 1974; Mycielska-Dowgiałło, 1978, 1996; Ludwikowska-Kędzia, 2000; Barczuk \& Mycielska-Dowgiałło, 2001; Dąbski, 2001; Vieira et al., 2003; Chlebowski \& Lindner, 2004; Krzyszkowski, 2010).

(3) Different density of minerals (Jęczmyk \& Kanasiewicz, 1970; Wajda, 1970; Racinowski 1992, 1995; Vieira et al., 2003).

All these parameters should be compared with the corresponding ones of potential source deposits. This may lead, among other things, to the reconstruction of energy levels and to estimates of the duration of a studied process in fluvial, aeolian, and shore environments (Urbaniak-Biernacka, 1975; Mycielska-Dowgiałło et al., 1990; Florek et al., 1990; Florek \& Mycielska-Dowgiałło, 1991; Rizzetto et al., 1998; Mycielska-Dowgiałło \& Woronko, 2004; Woronko, 2012; Weckwerth \& Chabowski, 2013).

\subsection{Applications of heavy-mineral research}

Based on the composition of heavy-mineral assemblages, climate characteristics can be reconstructed (Dymowska et al., 1984, Mycielska-Dowgiałło, 1992, 1988, 1993); this requires special attention for the opaque minerals and altered epidotes. Heavy-mineral assemblages are also particularly helpful in the stratigraphical positioning of deposits (Kosmowska-Ceranowicz, 1966, 1976, 1979, 1987; Mycielska-Dowgiałło \& Woronko, 2004; Bujak, 2010; Goździk et al., 2010; Roman, 2010).

In the last few years, more attention has been given to opaque heavy minerals (Barczuk \& Neibert, 2007). In addition to the identification of the opaque mineral species characterised by different resistance to chemical weathering and mechanical abrasion, attention should be given to their total percentage in the whole sample, as well as their relation to the percentage of transparent heavy minerals. The main indicative feature of opaque minerals (as total group in the whole sample) is their density, which is on average higher than that of the group of transparent heavy minerals.

The number of heavy-mineral species in Polish sediments is also worth mentioning. 
The less minerals most resistant to weathering, the older, in general, the sediment (for Polish sediments this mostly means: pre-Quaternary). A limited number of species in Quaternary deposits indicates as a rule that they have been subjected to earlier depositional/erosional cycles.

Numerous studies deal with regional characteristics of heavy-mineral assemblages in deposits such as loess, lacustrine silt, till, shore or fluvial deposits (Łydka \& Turnau-Morawska, 1967; Czerwonka \& Witek, 1977; Chlebowski \& Lindner, 1991; Racinowski, 1992, 2002, 2008, 2010; Kenig, 2009). Deposits of the same origin can be characterised by different heavy-mineral assemblages in different regions of Poland, depending on their relation with the source deposits.

\section{Methods}

Heavy-mineral analysis in Poland is commonly carried out according to the methods used in the studies made for the Detailed Geological Map of Poland at a scale of 1:50,000 (Kenig, 1999). The heavy minerals are separated in bromoform or another heavy liquid. Slides with the thus obtained heavy fraction are mounted using Canada balsam or other appropriate resins. Then opaque and transparent minerals are identified under a polarising microscope.

Several stages can be distinguished in the heavy-mineral analysis. The first stage is a complete analysis of the heavy minerals, dividing them into opaque and transparent minerals, with counting the percentage of each group. The second stage is the analysis of only transparent minerals, carried out for at least 300 grains. The total of the thus identified transparent heavy mineral grains is taken as $100 \%$ in order to calculate mineralogical coefficients such as the weathering index (W). The third stage can be similar if also the opaque minerals are analysed. Once more, at least 300 grains should be identified, treating them as $100 \%$.

In the case of difficult identification of the minerals, the grains that are very small and that form mixed minerals or that have been chemi- cally or mechanically altered, and of which the optical features are not clear, identification can be performed using an electronic microprobe (EDS), which gives much better results (Marcinkowski \& Starnawska, 2004). It should be stressed, however, that the possibility of using an electronic microprobe for the identification of heavy-mineral grains is limited because of the manpower needed and the high costs of the method.

The content of heavy minerals in the Polish Quaternary sediments is commonly of the order of $1 \%$, though much lower and much higher concentrations can occur (see Van Loon, 1972/1973). Heavy minerals occur mainly as grains with a diameter ranging from 0.5 to 0.01 $\mathrm{mm}$, but individual minerals reach their maximum concentration in different parts of this grain-size range (Mycielska-Dowgiałło, 2007). For example kyanite, staurolite and glauconite are most abundant in the range from 0.25 to 0.1 $\mathrm{mm}$, whereas amphibole and pyroxene tend to be $0.5-0.1 \mathrm{~mm}$.

\subsection{Number of counted grains}

Because the concentration of individual mineral species differs for different grain-size ranges, the analysis of heavy minerals should be carried out for a definite grain-size range (most often 0.2-0.1 $\mathrm{mm}$ and 0.12-0.06 mm), and only the results obtained in this way can be compared. Only in the case of loesses, in which $40-50 \%$ of grains have sizes from 0.01 to $0.05 \mathrm{~mm}$, Chlebowski \& Lindner (2004) propose that this fraction be used for the analysis of heavy and light minerals.

\section{Significance of the resistance of heavy minerals to chemical weathering and mechanical abrasion}

In order to determine the age and origin of deposits, it is very important to divide heavy minerals into opaque and transparent ones, and then into minerals of different resistance to chemical weathering and mechanical abrasion. 


\subsection{Resistance to chemical weathering and mechanical abrasion}

A list of heavy minerals, according to their resistance to both chemical weathering and mechanical abrasion was published by Racinowski (1995). He distinguished four groups of transparent heavy minerals: very resistant minerals (andalusite, topaz, brookite, rutile, tourmaline, zircon, corundum), resistant minerals (anatase, staurolite, kyanite, titanite, monazite), medium-resistant minerals (apatite, garnet, epidote, zoisite, sillimanite), and non-resistant minerals (glauconite, olivine, biotite, chlorite, pyroxene, amphibole).

A comparable list of such minerals was published by Kenig (1999) in the work 'Methods of working out of the Detailed geological map of Poland at a scale of 1:50,000'. She ranked the minerals from the least to the most resistant to mechanical abrasion. These are (in this order): amphibole, pyroxene, biotite, chlorite, epidote, garnet, tourmaline, zircon, rutile, titanite, kyanite, staurolite, andalusite, sillimanite, apatite, topaz, corundum.

A more extended classification of heavy minerals, viz. concerning resistance to both weathering and mechanical abrasion was published by Chlebowski \& Lindner (2004). They distinguished four groups of minerals plus a fifth group with minerals that are especially susceptible to deflation and aeolian transport. These five groups are:

(1) most resistant group: anatase, andalusite, zircon, kyanite, corundum, monazite, rutile, staurolite, tourmaline, topaz, titanite;

(2) less resistant group: apatite, epidote, garnet, sillimanite;

(3) non-resistant group: amphibole, pyroxene;

(4) least resistant group: glauconite;

(5) group especially susceptible to deflation and aeolian transport (minerals with a lamellar habit): muscovite, biotite, chlorite.

The above classifications do not take into consideration opaque minerals, which have also a different resistance to mechanical abrasion and chemical weathering. Ilmenite is very resistant, and titanomagnetite is resistant. Magnetite and hematite are characterised by a gradually lower resistance. The least resistant seem to be siderite, limonite, goethite, pyrite, and marcasite, which are easily destroyed by mechanical abrasion and chemical weathering. In some profiles that were investigated during the work for the 'Detailed geological map of Poland at a scale of 1:50,000', the content of ilmenite reached $40-50 \%$ of the total amount of opaque heavy minerals. Ilmenite is commonly accompanied by very resistant transparent minerals: topaz, rutile, tourmaline, zircon and garnet. Secondary iron oxides such as siderite and pyrite are usually not found together with ilmenite (Marcinkowski, 1999).

\subsection{Weathering coefficient}

Racinowski \& Rzechowski (1969) established a dimensionless weathering coefficient for heavy minerals, for the classification of tills:

$$
\mathrm{W}=(\mathrm{St} / \mathrm{T}) \mathrm{N}
$$

where $\mathrm{T}$ is the percentage of stable minerals that are resistant to abrasion (zircon, rutile, tourmaline, staurolite, kyanite) if the total of transparent heavy minerals is taken as $100 \%$; $\mathrm{St}$ is the percentage of medium-resistant minerals (apatite, epidote, garnet, sillimanite), and
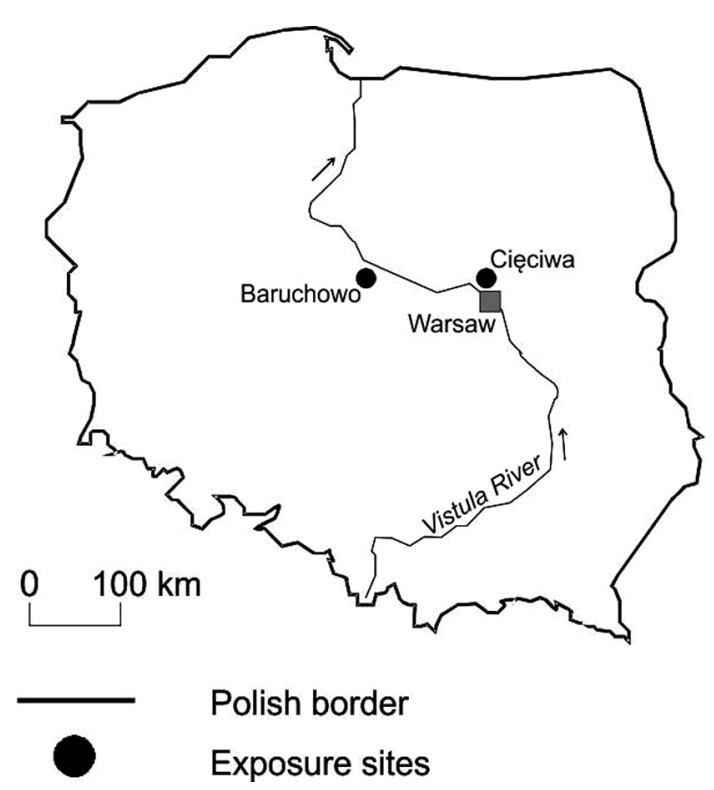

Fig. 1. Location of the dune at Cięciwa and of the Baruchowo exposure. 


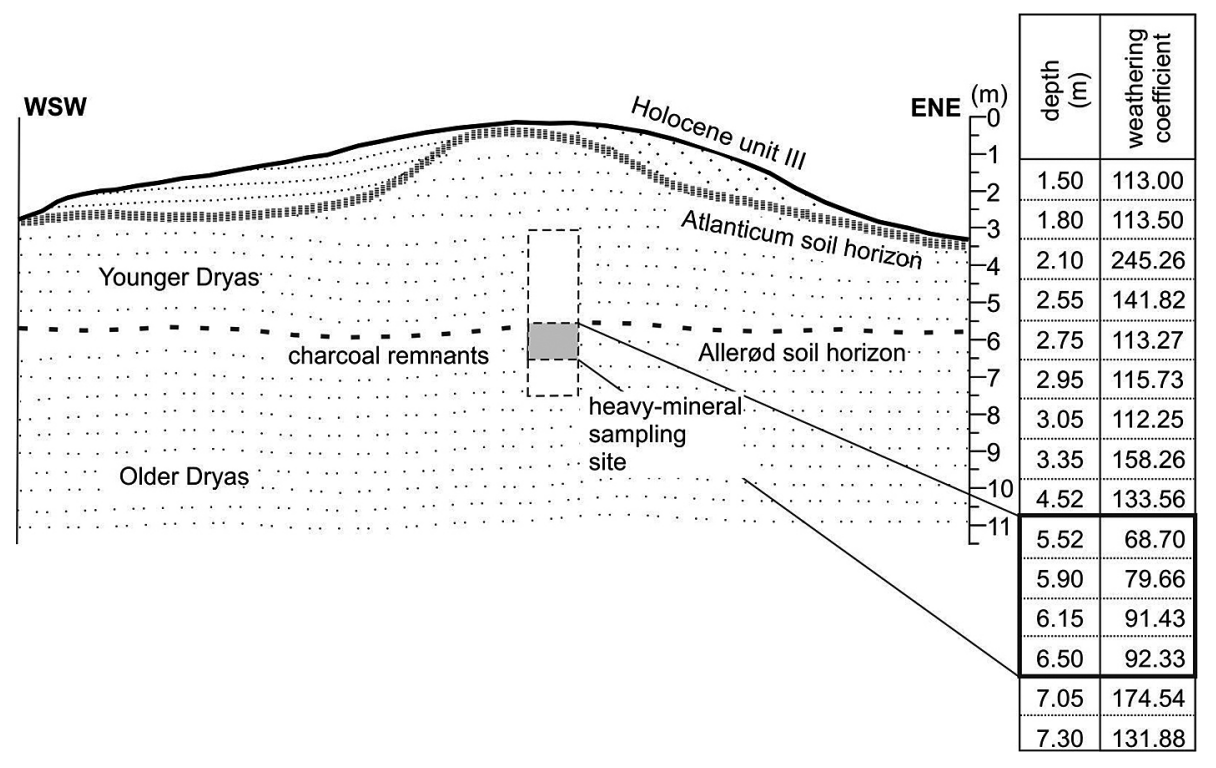

Fig. 2. Profile of the Cięciwa dune and distribution of the weathering coefficient, calculated on the basis of an analysis of heavy minerals in the $0.16-0.125 \mathrm{~mm}$ fraction.
$\mathrm{N}$ is the percentage of non-resistant minerals (amphibole, pyroxene, biotite, chlorite).

The weathering coefficient is used, among other things, to determine the degree of weathering in palaeosols and their residual horizons (Kamińska et al., 1986; Dzierwa \& Mycielska-Dowgiałło, 2003), as well as in lithological profiles (Roman, 2010). It should be stressed, however, that in extreme cases, when opaque minerals are exceptionally dominant $(>90 \%)$ in the heavy fraction in comparison with transparent minerals $(<10 \%)$, calculation of the weathering coefficient is thought to be unjustified.

In the exposure at Cięciwa, the Allerød soil is well visible in one of the walls, and in the other wall it occurs as a weakly visible streak of charcoal. However, the analysis of heavy minerals and the calculation of the weathering coefficient made it possible to distinguish the previously present soil horizon because it showed a distinct lowering of the weathering coefficient (Figs 1, 2).

The weathering coefficient was also calculated for the Baruchowo exposure (Roman, 2010) (Figs 1, 3). For the preglacial layers (B1) it was calculated as 1-5, and for the Quaternary layers 157 (B2), 263 (B3a), and 350 (B3b). Such large differences between the values of the weathering coefficient calculated for the Quaternary deposits and older ones (preglacial in this case) prove the boundary between them unambiguously.

\subsubsection{Weathering coefficients in southern Poland}

It should be emphasised that the above values of the weathering coefficient are typical of northern and central Poland with its thick covers of glacial deposits. Towards the south, in the upland and mountain zones, the values of this coefficient are much lower for the Quaternary deposits. For example, the coefficient in the Belnianka River valley in the Holly Cross Mountains ranges from 0.52 to 3.97 (for slope deposits) and from 0.93 to 41.82 (for fluvial deposits) (Ludwikowska-Kędzia, 2000, 2007; Wachecka-Kotkowska \& Ludwikowska-Kędzia, $2007,2013)$. These values reflect a high proportion of local material from the weathered preQuaternary (Palaeozoic, Mesozoic and Palaeogene-Neogene) rocks. In the heavy-mineral assemblages, this material is characterised by a dominance of resistant minerals.

\subsection{Mineralogical coefficients}

Based on the relationships between some heavy mineral species and also between their groups (e.g. non-resistant vs. resistant minerals), the depositional environments can be reconstructed (cf. Woronko, 2013). These relationships are presented as so-called 'mineralogical coefficients' (Marcinkowski, 2007):

(1) the ratio between the percentages of amphibole and garnet (the A-coefficient); 


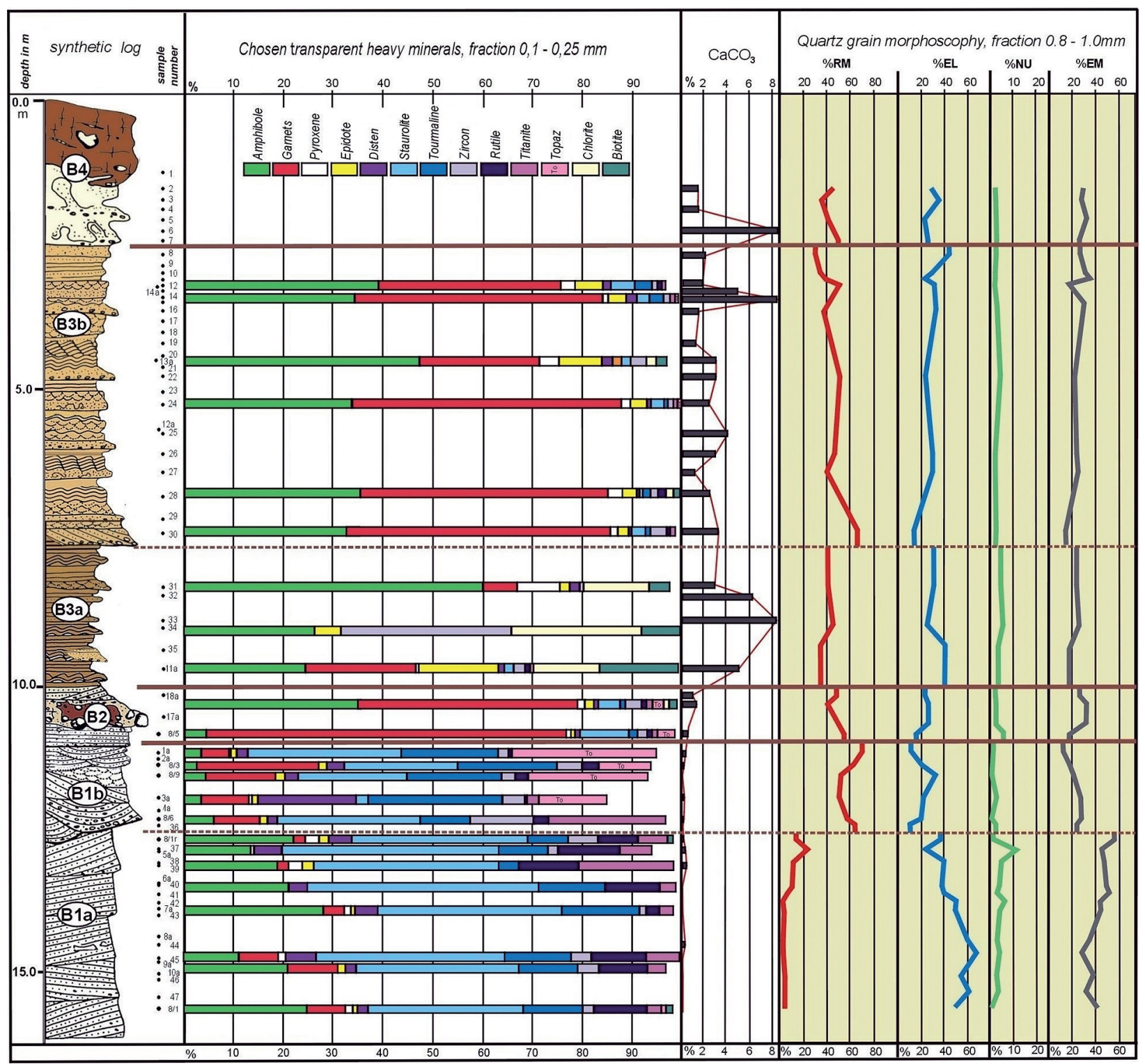

Fig. 3. Results of the investigations in the Baruchowo exposure (according to M. Roman).

$\mathrm{B} 1 \mathrm{a}=$ preglacial, channel deposits of a sand-bed braided river; $\mathrm{B} 1 \mathrm{~b}=$ preglacial, channel deposits containing aeolian deposits, B2 = fluvioglacial, residual deposits (Narevian = Menapian glaciation?); B3a = distal subaqueous deposits; $\mathrm{B} 3 \mathrm{~b}=$ proximal subaqueous deposits; $\mathrm{B} 4=$ slope deposits.

(2) the ratio between the percentages of the minerals that are non-resistant to mechanical abrasion (amphibole, pyroxene, biotite, chlorite) and the resistant species (garnet, tourmaline, zircon, rutile, kyanite, staurolite, andalusite, sillimanite, and topaz) (the B-coefficient).

The A-coefficient is used as a supportive tool for the reconstruction of the depositional environment (e.g. aeolian, fluvial, fluvioglacial, glacial) (Fig. 4). A significant domi- nance of garnet over amphibole (A-coefficient below 0.5) is typical of aeolian deposits, but the heavy-mineral grains should also be well rounded and well sorted. Grain roundness need, however, not be the result of deposition in an aeolian environment, but can also point at subaqueous deposition, namely if the grains were seized during aeolian transport by water surfaces and incorporated into subaqueous deposits. The value of the B-coefficient in aeolian deposits is sometimes be- 


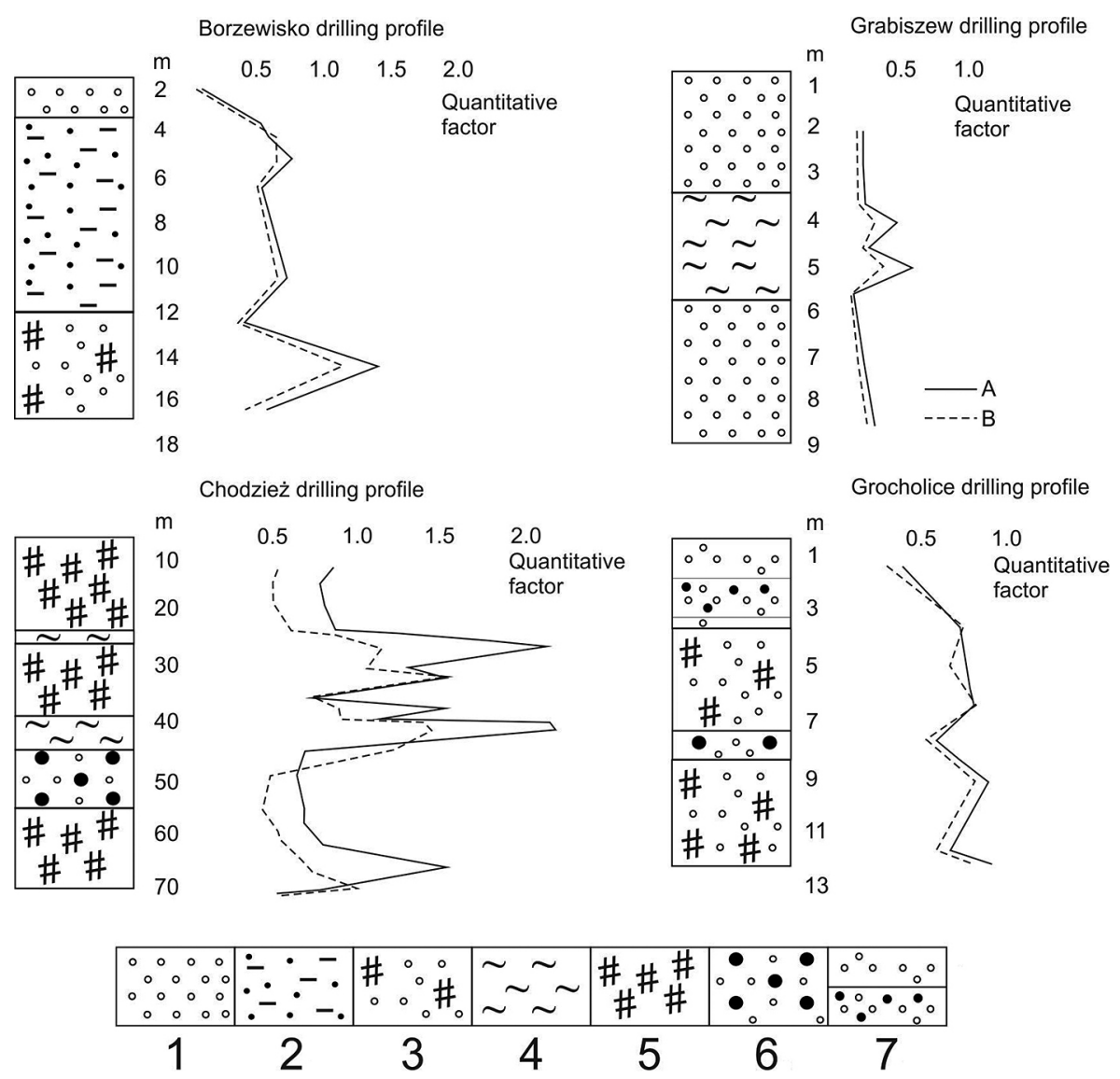

Fig. 4. Diagrams of the A- and B-coefficient values in the Quaternary deposits from boreholes: Borzewisko, Grabiszew and Grocholice (Uniejów sheet), and Chodzież (Chodzież sheet in central Poland).

1 = medium-grained aeolian sand; 2 = clayey sand; $3=$ sandy till; $4=$ mud; $5=$ till; $6=$ unsorted fluvioglacial sand; $7=$ medium-grained fluvioglacial sand, aeolian at the top.

low 0.1 , which indicates that minerals resistant and very resistant to mechanical abrasion constitute over $90 \%$ of the transparent heavy minerals. An increase of the A-coefficient to a value of 1 or more is related to lack of sorting or weak sorting. It is accompanied by the appearance of iron oxides, siderite-ferruginous concretions and sulphides which all are non-resistant to abrasion, while the grains of resistant minerals are poorly rounded. This is most often found in glacial tills and fluvioglacial deposits.

When the values of the A- and B-coefficients are low, sulphides, carbonates and secondary iron oxides (pyrite, limonite, goethite, lepidocrocite) tend to be lacking or present in small amounts, whereas the mineral species that are resistant to abrasion, primary iron oxides (ilmenite, titanomagnetite, magnetite), are present in large amounts.

\subsection{Weathering vs. abrasion resistance}

The resistance of some heavy minerals to chemical weathering differs from their resistance to mechanical abrasion. Garnet is a good example (Morawski, 1968), as it is medium resistant to chemical weathering but very resistant to mechanical abrasion. The content of garnet consequently becomes relatively higher in deposits that have been eroded and redeposited many times, which is common for aeolian (Kamińska et al., 1986), fluvial (Rzechowski et al., 1975; Florek et al., 1987; Florek \& Mycielska-Dowgiałło, 1991; Weckwerth, 2013) and beach (Racinowski, 1974, 1992) environments (Fig. 5); its concentration decreases, in contrast, in soil horizons.

The significance of the high resistance of garnet to mechanical abrasion is well illustrated by the deposits from the Baruchowo pro- 


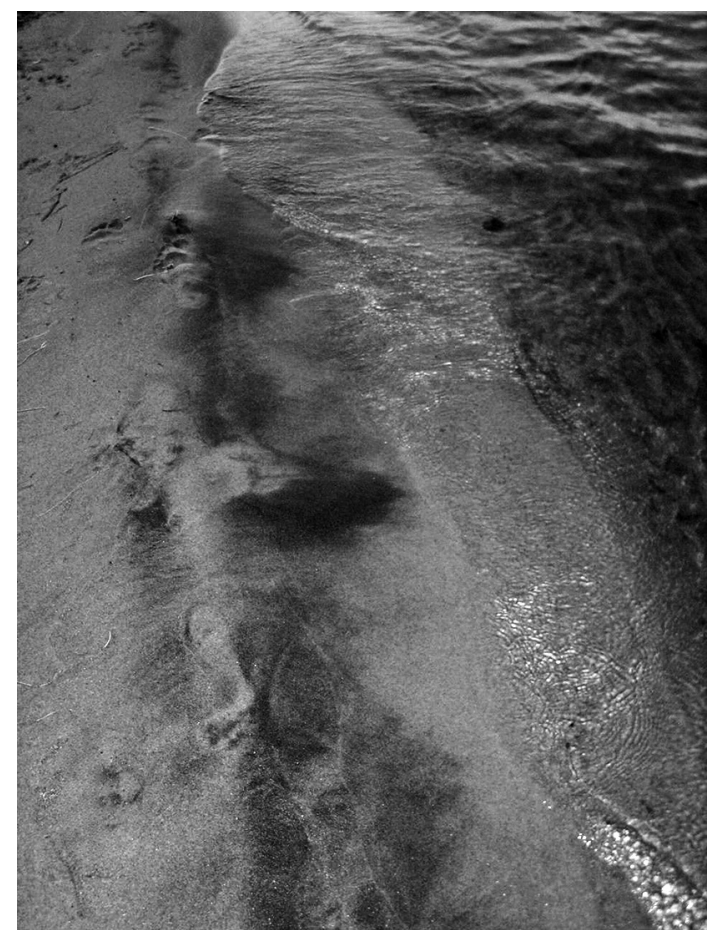

Fig. 5. Concentration of heavy minerals (dark on the photo) that are particularly resistant to mechanical abrasion. Beach zone of Lake Meech, Gatineau Park, Canada (Photo B. Woronko).

file (Fig. 3). A high garnet content (40-72\%) is found in the B2 unit. This indicates repeated redeposition of fluvioglacial deposits. The B3b unit, composed largely of deposits from high-energy currents, is also characterised by a high content of garnet. Repeated reworking of fluvial deposits that have been gradually relatively enriched in minerals resistant to mechanical abrasion, thus can also occur in this environment.

Tourmaline is another mineral that is very well resistant to mechanical abrasion. Its content increases relatively in deposits that were affected by long-lived aeolian processes (Goździk, 1980; Manikowska, 1985). Further, it seems that amphiboles are slightly more resistant to chemical weathering than pyroxenes, so that their content in soils can become relatively higher than that of pyroxenes (even if their absolute quantity is lower than in the substratum), whereas, on the other hand, amphiboles are less resistant to mechanical abrasion, so that their content decreases faster than that of pyroxenes in deposits affected by long-lived aeolian processes (Goździk, 1980; Manikow- ska, 1985; Krzyszkowski, 1995; Mycielska-Dowgiałło, 1995). This phenomenon demands further study.

\section{Significance of the habit of heavy minerals}

The group of micas with their lamellar habit (biotite, chlorite and muscovite) form a special group among the heavy minerals. Because of its somewhat varying density, muscovite can be found in both heavy and light fractions. In order to determine the total content of muscovite in a deposit, its contents in both fractions should therefore be added up.

Because of the lamellar habit of biotite, chlorite and muscovite, their amount in deposits significantly decreases during deflation (Kamińska et al., 1986; Mycielska-Dowgiałło, 1993; Barczuk \& Mycielska-Dowgiałło, 2001) and fluvial sorting (in repeatedly reworked deposits in channels), whereas their contents remain relatively high after settling from suspension in floodplain deposits (Racinowski, 1974; Rizzetto et al., 1998) and after surface washing caused by rainfall (Vieira et al., 2003).

The presence or absence of lamellar minerals in a sediment is very important for the reconstruction of the morphodynamic processes (such as channel or overbank transport in rivers, and aeolian suspension or saltation transport) as well as for the determination of the stratigraphical position of the sediment. This is well illustrated by the investigation of the Baruchowo exposure (Fig. 3). In the upper preglacial unit (B1b), the high roundness and frosting of quartz grains (RM: roundmat; Cailleux, 1942) indicate intensive aeolian activity. At the same time, these deposits are characterised by the complete absence of lamellar minerals in the heavy fraction. This is most likely the result of deflation of the grains from the source deposits, but it may also be due to the absence of these minerals, which are derived from Scandinavian source rocks, in the whole preglacial unit. The lamellar minerals appear only in the Quaternary deposits (B2, B3a, B3b), and their varying contents depend on the facies. Their content is highest $(>30 \%)$ in the sub- 
aqueous deposits (B3a). They were delivered by both water and wind, and quietly settled in the water body. In the sediments deposited by high-energy currents (B2 and B3b), the content of lamellar minerals is only $1-2 \%$. The transport thus controlled the frequency of the lamellar species.

The analysis of transparent heavy minerals in channel and floodplain sediments from the San River valley in Przemyśl indicates that the channel facies is distinctly impoverished in biotite and chlorite (only $4 \%$ of the assemblage), while the floodplain sediments are enriched in these minerals (from 25 to $45 \%$ ). By contrast, the content of garnets in the channel facies is $81 \%$, and in the floodplain facies 18\% (Racinowski, 1974).

The investigations of several dozens of geological profiles from central and northern Poland (Woronko, 2012) indicate that a high concentration of well rounded and frosted quartz grains of sand size is typical of the proglacial fluvioglacial deposits overlying the interglacial deposits (Mycielska-Dowgiałło \& Woronko, 2004). These grains point at intensive aeolian activity, and can indicate climate conditions. In the same deposits, varying amounts of lamellar heavy minerals occur, depending on whether they were deposited in a channel or on a floodplain. Just like in the fluvial deposits of the San River (south-eastern Poland), lamellar minerals are absent in the channel sediments, but present in the floodplain deposits (which, however, are rare under periglacial conditions).

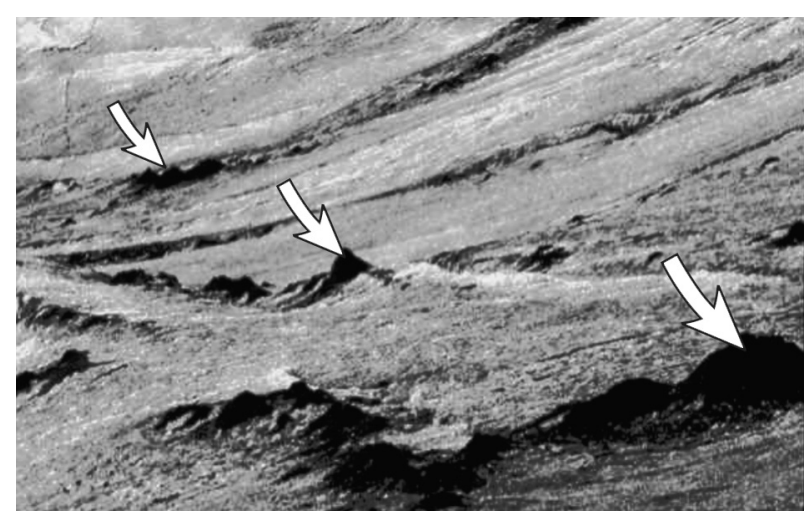

Fig. 6. Dark, sandy/silty aeolian deposits exposed after ablation along crevasses in the Flaa glacier, Iceland. The height of arrowed mounds is approx. $0.4 \mathrm{~m}$ (Photo M. Dąbski).
Studies carried out in Iceland, on the surface of the Flaa glacier, showed the occurrence of aeolian silt deposits in which biotite constituted up to $70 \%$ of the transparent heavy minerals (Dąbski, 2001) (Fig. 6).

\section{Significance of the density of heavy minerals}

Heavy-mineral species have different densities. The highest densities are found among the opaque minerals (e.g., magnetite $5.2 \mathrm{~g} / \mathrm{cm}^{3}$, pyrite $5.0-5.2 \mathrm{~g} / \mathrm{cm}^{3}$, and ilmenite $4.5-5.0 \mathrm{~g} /$ $\mathrm{cm}^{3}$ ). Among the transparent minerals, zircon $\left(4.5-4.7 \mathrm{~g} / \mathrm{cm}^{3}\right)$ and rutile $\left(4.2-5.5 \mathrm{~g} / \mathrm{cm}^{3}\right)$ have a high density. Garnets are characterised by various densities (from 3.2 to $4.4 \mathrm{~g} / \mathrm{cm}^{3}$ ), depending on their type.

Based on the different density and grain habit of heavy minerals, hydro- and aerodynamic equivalents of the various values (high, medium and low) were distinguished (Racinowski, 1995; Giriat, 2003). High equivalents are typical of deposits with a high concentration of minerals that are difficult to move (e.g. with high density), i.e. they become concentrated in river channels and deflation areas of desert ergs, from which all more easily transported minerals were removed (e.g. minerals with a lamellar habit). In contrast, low equivalents are typical of deposits in which minerals easy to move dominate. These minerals can be repeatedly reworked in river deposits and in dunes.

Density segregation of heavy minerals in preserved infillings of frost wedges on the Kolno plateau is known from a phase of strong degradation of permafrost. The fissures formed wide polygons that became filled with water-saturated sediments, as indicated by the preserved deformation structures (cf. Van Loon, 2009b). The analysis of the heavy minerals in the vertical infilling indicated an increase of minerals with a higher density towards the bottom (Korotaj \& Mycielska-Dowgiałło, 1982).

A similar example of density segregation of heavy minerals in frost wedges was described from the northern periphery of the Holy Cross Mountains (Barcicki \& Ciupa, 2007). Based on 
the shape of these forms and the textural features of the deposits, two stages of their development were recognised, which are particularly well expressed in the vertical distribution of garnet. Garnet types with the highest density, spessartine $\left(4.2 \mathrm{~g} / \mathrm{cm}^{3}\right)$ and almandine $(4.3 \mathrm{~g} /$ $\mathrm{cm}^{3}$ ), are concentrated in the bottom parts of the wedges, for each of the two developmental stages. The wedges were filled, as on the Kolno Plateau, during permafrost degradation, under rather wet conditions. This is indicated by the poor roundness of the quartz grains in the wedges on in the Kolno Plateau (indicating a lack of aeolian processes), as well as by the increased amount of biotite in the top parts of these infillings. Biotite, transported by wind, was probably seized by small water bodies and muddy surfaces.

\section{Dynamics of fluvial and shore processes recorded in heavy-mineral assemblages}

Based on investigations of the fluvial sediments of the Vistula River, units deposited during the Last Glacial by a braided river have a positive sediment balance, whereas the overlying units, accumulated in the temperate climate of the Holocene by a meandering river have a negative sediment balance (Mycielska-Dowgiałło, 1977, 1978; Florek et al., 1987). These two units differ with regard to their structural and textural features. The braided-river sediments are characterised by a heavy-mineral assemblage that varies both vertically and laterally. The lack of mineral segregation indicates a continuous build-up in the channels, and a continuous supply of fresh weathered material from the catchment area. In the meandering channels, in contrast, vertical segregation of the heavy minerals took place, which indicates repeated reworking, resulting in a gradual increase in the proportion of heavy minerals resistant to mechanical abrasion (e.g. garnet), accompanied by a decrease in the amount of non-resistant minerals (amphibole and pyroxene) (Florek et al., 1987; Florek \& Mycielska-Dowgiałło, 1991).
Analyses of heavy-mineral assemblages from floodplain deposits of the Po River near Este in Italy and from the overlying aeolian covers showed a high content of micas and a low content of garnet in the floodplain deposits, whereas the aeolian deposits are characterised by a predominance of garnet and a low mica content. This indicates quiet deposition on the floodplain, and repeated reworking of the aeolian coversands (Rizzetto et al., 1998).

Interesting data have also been obtained from investigations of the Baltic shore (Racinowski, 1974, 1992). The comparison of heavy-mineral assemblages identified in beach sands, near-shore sands, fluvioglacial deposits and tills indicates that the lowest mean content of amphibole and the highest mean content of garnet occur in the $0.12-0.25 \mathrm{~mm}$ fraction of the beach sands. This can be explained by the repeated swash and backwash of the material in the beach zone, resulting in sorting of the minerals. The beach sands become thus impoverished in minerals that are the least resistant to mechanical abrasion, and enriched in the very resistant garnet (Fig. 5).

\section{Significance of the composition of heavy-mineral assemblages}

The composition of a heavy-mineral assemblage can be used for interpretation of various parameters, such as the duration of the depositional process, the climatic conditions during and/or after deposition, and the relative stratigraphical position of a deposit.

\subsection{Composition of heavy-mineral assemblages as a proxy for the duration of accumulation}

Depending of the duration of aeolian processes, the degree of transformation of the heavy-mineral assemblages in source deposits into aeolian ones (= degree of aeolisation) is different. This can be recorded in several features such as the heavy-minerals assemblage, the percentage of quartz grains in the sand fraction, the degree of sorting, the degree of 
roundness and frosting of quartz grains, and the micromorphology of these grains, as visible under a scanning electron microscope (Mycielska-Dowgiałło, 1992, 1993).

Comparison of aeolian deposits from southern Sweden with similar deposits from Poland (not covered by ice during the last glaciation), as regards the degree of modification of their textural features in relation to their direct substratum, indicates considerable differences, which are a proxy for the duration of the aeolian process (Mycielska-Dowgiałło, 1993). In relation to their substratum, the dune deposits from southern Sweden are not enriched in quartz, nor in heavy minerals resistant to mechanical abrasion. They are only impoverished in micas. In contrast, the dune deposits from the Vistula River valley near Płock are, again in relation to their substratum, considerably enriched in quartz and heavy minerals resistant to mechanical abrasion, and impoverished (particularly in the upper parts of the dunes) in micaceous heavy minerals, which are easy to remove during aeolian activity. The dunes in southern Sweden were formed in a short time, not longer than several hundreds of years, after the ice-sheet retreat and before vegetation protected the sediments, whereas the dunes from the Vistula River valley near Płock were subjected to aeolian activity for at least the whole decline of the Last Glacial (approx. 4000 years).

\subsection{Composition of heavy-mineral assemblages as a proxy for climate conditions}

Investigations of the textural features of dunes and their substratum in six deserts of south-western Asia have shown that calculation of the percentage of opaque minerals and of the ratio between non-altered epidotes and altered ones is a valuable tool for the reconstruction of climatic conditions in warm and dry areas (Dymowska et al., 1984; Mycielska-Dowgiałło, 1992).

Among the dune deposits investigated in the six deserts, those from the Salt and Lotha deserts (in the eastern part of Iran) have the highest percentage of opaque minerals (38-
$31.4 \%)$, and the highest ratio of non-altered epidotes to altered ones (1.8-1.5). The dune deposits are supplied with freshly weathered material (with a high content of non-altered epidotes) by streams flowing down from the surrounding hills. At the same time, under dry and warm climate conditions, iron compounds, due to intensive evaporation, precipitate on the mineral grains, causing an increase in the percentage of opaque minerals.

The dune deposits of the Kharan and Karakum deserts (Afghanistan) have an average percentage of opaque minerals (29.0-22.5\%), and the highest percentage of altered epidotes (the ratio of non-altered epidotes to altered ones is $0.5-0.4$ ). This results presumably from a long history of their source deposits, during which epidotes were being altered under warm and humid climate conditions. Also the present climate, warm and dry, favours the formation of opaque minerals.

The dune deposits of the Thar and Thal deserts (Pakistan) have the lowest percentages of opaque minerals (10.7-10.3\%), and a slight dominance of altered epidotes over non-altered ones (the ratio amounts to 0.9-0.8). This results from a higher humidity in these warm deserts, hampering the precipitation of iron compounds on mineral grains. The composition of the source deposits on high terraces, which were formed under considerably more humid climate conditions than the present ones, may also play a role.

In warm and wet climates, rutile is formed during the weathering of ilmenite, and the released iron combines with oxygen, forming iron oxides. This process can develop on a large scale, and rutile concentrations of economic importance can thus be formed (Marcinkowski \& Wiszniewska, 2007). The most common product of the hydration of titanium minerals is leucoxene, which is a heterogeneous and aggregate form of several polymorphic varieties of titanium minerals (Marcinkowski, 1990).

Under cold-climate conditions, the composition of heavy-mineral assemblages point at intensification of aeolian processes, which indirectly indicates cooling and drying of the climate, a change of river channel patterns, and to a lower density of the vegetation cov- 
er, thus contributing to an increased supply of weathered material from the catchment area. It must be noted, however, that the composition of heavy-mineral assemblages is just only one of the textural features of sediments, and that only a detailed analysis of the various features can give reliable results.

\subsection{Composition of heavy-mineral assemblages as a tool for stratigraphical positioning}

The compositions of heavy-mineral assemblages are in Poland often the main indicator of the stratigraphical boundary between the Neogene and the Quaternary. This also makes it possible to distinguish between preglacial and glacial Quaternary deposits (Fig. 3). Investigation of preglacial deposits using heavy-mineral analysis was initiated in Poland by Kosmowska-Ceranowicz (1966, 1976, 1979, 1987), Sarnacka \& Krysowska-Iwaszkiewicz (1974) and Krysowska-Iwaszkiewicz (1974). A detailed stratigraphical division of preglacial deposits, based on the composition of heavy-mineral assemblages and the morphology of quartz grains, was published by Roman (2010). A subdivision of the preglacial deposits from the southern part of the Mazovia Lowland into facies was presented by $\mathrm{Bu}-$ jak (2010). He found that the preglacial deposits west of the Vistula River valley have mostly a channel facies and that they contain heavy minerals most resistant to chemical weathering and mechanical abrasion, whereas those east of the river valley have a floodplain facies, with a predominance of chlorite (accompanied by the above-mentioned resistant minerals) in the heavy fraction.

The contents and composition of heavy and light fractions, including quartz, provide much information that helps to establish the stratigraphical position of the various Quaternary deposits. Such studies complement the results of analyses of the roundness and frosting of sand-sized quartz grains and of their surface micromorphology (Barczuk \& Mycielska-Dowgiałło, 2001; Mycielska-Dowgiałło \& Wo- ronko, 2001; Woronko, 2001). In specific cases, detailed analysis of the mineral composition of cores from boreholes makes it possible to deduce glaciotectonic deformation (Goździk \& Wiatrak, 2001).

The analyses of heavy minerals carried out for the 'Detailed geological map of Poland at a scale of $1: 50,000$ ', in order to determine the boundary between the Quaternary and its substratum, in some cases revealed a truly clear change of the mineral composition at this boundary, particularly where the stratigraphical boundary coincides with a change in lithology, i.e. where Quaternary permeable deposits overlie impermeable pre-Quaternary rocks, so that reducing conditions developed. Under such conditions, pyrite often constitutes several dozens of per cent of the heavy fraction. Pyrite is often accompanied by a considerable amount of siderite (in the form of concretions) but in extreme cases it is the only mineral (Marcinkowski, 2007, 2009).

\section{Regional variations in the heavy- mineral assemblages of Quaternary deposits}

The composition of transparent heavy-mineral assemblages of specific types of sediments (e.g., tills, fluvioglacial sands, muds, fluvial sands and dune sands) is qualitatively very similar all over Poland. These assemblages are composed of a wide mineral spectrum, including minerals of different resistance to weathering. The percentages of the individual transparent heavy minerals are different, however (Racinowski, 2010); it depends largely on the source deposits, because there are, besides rather uniform sources such as glacial deposits from a specific area of the Baltic Sea Basin or Scandinavia, also local sources such as weathered material from mountain areas and eroded pre-Quaternary rocks. The heavy-mineral assemblages derived from such Polish pre-Quaternary rocks differ, obviously, considerably from those that ultimately are derived from the Baltic or Scandinavia. 


\subsection{Tills}

The analyses of heavy minerals in tills, their roundness, grain-size distribution, mineral sorting, give highly diverging results. The composition of heavy-mineral assemblages in tills depends on several factors such as the mineral composition of the deposits eroded by the advancing ice sheet, and also the post-depositional processes in a till. The proportions of the mineral groups of minerals that are non-resistant and resistant to abrasion, as well as those of the opaque and transparent minerals fluctuate consequently. Tills are characterised by a wide variety of heavy-mineral species: they include most of the minerals present in Pleistocene deposits (Marcinkowski, 2007; Derkacz et al., 2009).

The ratio between opaque and transparent minerals tends to increase downwards, towards the oldest deposits. This is due mainly to pyrite and siderite, which minerals become more frequent towards the bottom. They may either be formed diagenetically in situ in reducing environments or be inherited from the pre-Quaternary sediments eroded by the ice sheet. Ilmenite, as the most resistant opaque mineral in tills, is derived from Scandinavian igneous rocks. It was transported during successive ice-sheet advances. It therefore usually occurs in the form of well rounded grains and in higher amounts than other heavy minerals, which are less resistant to weathering (Marcinkowski et al., 2007).

\subsection{Fluvioglacial deposits}

Fluvioglacial deposits are in general characterised by a varying composition of their heavy-mineral assemblages, which contain minerals with both high and low hydrodynamic equivalents. The ratio between the minerals resistant to abrasion and the non-resistant ones fluctuates considerably, and depends on the composition of the tills that are their source material, and on the transport distance.

\subsection{Glaciolacustrine deposits}

Glaciolacustrine deposits contain very finegrained heavy minerals, most often with low hydrodynamic equivalents. These are mostly fine lamellar minerals (biotite, chlorite, muscovite), and fine grains of amphibole, pyroxene and glauconite. Secondary iron oxides (limonite, goethite, lepidocrocite, syderogel) constitute a low percentage of the heavy fraction. The content of garnet and minerals resistant to abrasion are commonly also low.

\subsection{Fluvial deposits}

The mineral heavy-composition of fluvial deposits depends on the conditions during erosion, transport and deposition of the material, including the geological structure and relief of the catchment area and the climate. As mentioned above, the climate influences the river channel pattern, which in turn determines the formation of different types of fluvial deposits and their mineralogical characteristics.

\subsection{Aeolian deposits}

The composition of the heavy-mineral assemblages in aeolian deposits depends on the duration of the deflation process and on the source deposits (Mycielska-Dowgiałło, 1993, 2001). In Poland this dependence is best visible for the area covered by ice during the last glaciation (i.e. northern Poland, which was affected by relatively short-lived aeolian activity). The longer the duration of the aeolian processes, the higher the content of minerals resistant to mechanical abrasion and the lower the content of micas in a deposit. A slight change of the energy level in an aeolian environment results in the sorting of minerals according to their density (Marcinkowski et al., 2009).

\subsection{Shoreline deposits}

Shore-zone sediments (beach environment) contain different percentages of heavy miner- 
als. In beach sands this percentage ranges from below $0.2 \%$ to $6 \%$ (Racinowski, 1974). The assemblage is commonly largely composed of opaque (ore) minerals, garnet and amphibole.

The weight percentage of the heavy fraction in near-shore marine deposits is slightly higher. In this case the main components of the heavy fraction are also opaque minerals, garnet and amphibole, but they are accompanied by low percentages of biotite and epidote (Racinowski, 1974).

\subsection{Processes involved}

The heavy-mineral assemblages from a specific site can reveal differences, e.g. between successive till layers or between a specific layer and the pre-Quaternary substratum. The values of the weathering coefficient (Racinowski \& Rzechowski, 1969) of successive tills tend to increase towards the younger till layers. This is due to the exaration of the substratum by the ice sheet: the earlier ice sheet exarated mostly the weathering covers of the Neogene and Palaeogene layers, which contain almost exclusively minerals resistant to chemical weathering. The oldest till thus contains the highest proportion of the most resistant minerals. The successively advancing ice sheets exarated the deposits left by the preceding ice sheets and at the same time incorporated freshly weathered material from Scandinavia. Thus the ratio of resistant minerals to non-resistant ones decreases with till age. The percentage of the opaque minerals can decrease, whereas that of the sum of garnet, amphibole and pyroxene can increase. This is well illustrated by the results of heavy-mineral analysis of both pre-till deposits and the lower and upper tills from Marantów near Konin (Łydka \& Turnau-Morawska, 1967). The sums of the percentages of garnet, amphibole and pyroxene are for the pre-till deposits $18+10+0$ $=28$, for the lower till $20+17+0=37$, and for the upper till $23+20+1=44$.

The process of exaration can also be reflected in other textural features of the bottom parts of tills. If till overlies deposits with a high degree of aeolisation, its bottom parts tends to contain a considerable proportion of well rounded and frosted quartz grains (Barcicki, 1990; Mycielska-Dowgiałło \& Woronko, 2001; Woronko, 2012).

Heavy-mineral analysis is often used for the identification of the source areas of material, and well as for transport routes of marine currents and rivers. It also may reveal the source areas of aeolian sands and loesses, to distinguish stages of secondary modelling of dunes, and to draw conclusions about wind energy and direction (Mycielska-Dowgiałło, 1978, 1980).

It should nevertheless be realised that the significance of heavy-mineral analysis, used for the interpretation of depositional mechanisms, environmental facies, energy level involved and age, can vary from highly valuable to only almost negligible, partly depending on the results obtained with other types of analysis.

\section{Conclusions}

Investigation of heavy minerals was initiated in Poland after the Second World War, and since then developed parallel to the development of other research methods. Special attention was and still is devoted to transparent heavy minerals. The composition of heavy-mineral assemblages is one of the main characteristics of sediments.

The main parameters of heavy minerals that can be used for interpretation of the origin of a sediment, the energy and duration of the depositional processes, the stratigraphical position of a sediment, etc., can be summarised as follows.

(1) The various heavy-mineral species have different resistances to chemical weathering and mechanical abrasion. Several classifications exist that express this qualitatively. Good resistance against chemical weathering need not be accompanied by good resistance to mechanical abrasion, and vice versa.

(2) The various heavy-mineral species have different habits, which is important for sorting during transport and deposition in fluvial, aeolian and shore environments (note that transport commonly results in rounding of in- 
itially idiomorphic grains). Particularly micas deserve attention, because they have a lamellar habit. Minerals of this group are most quickly removed during aeolian deflation and during fluvial and shore activity. They accumulate during a decreasing energy of wind or water and can also be seized by water surfaces while being carried by wind.

(3) The various heavy-mineral species have different densities, which plays a major role during sorting processes. Density-based sorting of heavy minerals is known from frost wedges that became filled with sediment during degradation of permafrost. Based on their density of heavy minerals and their aero- and hydrodynamic equivalents, various aeolian and fluvial facies can be recognised, which allows interpretation of the erosional and accumulation sections of river channels as well as areas of deflation and aeolian accumulation.

The above features should ideally be studied in both transparent and opaque minerals. Investigation of opaque minerals is, however, still in an initial stage in Poland.

The results of heavy-mineral analysis add often valuable information analyses of other textural features. As an example, joint analyses of fluvial deposits along the Vistula River made it possible to distinguish stages in valley development, characterised by different energy levels and a positive or negative sedimentation balance, thus indirectly providing a proxy to reconstruct climate conditions.

Based on the comparison of heavy-mineral assemblages (e.g. the ratios between resistant minerals and non-resistant ones) in sediments of different origin, the intensity of sorting processes could be estimated, and indirectly also the depositional environment.

Comparative analysis of textural features (including heavy minerals) of a sediment and of its source deposits can be used to determine the duration of the accumulation.

Based on the composition of a heavy-mineral assemblage (especially the percentage of opaque minerals) and the way in which individual heavy minerals were affected by chemical processes, the climate conditions under which the sediment was formed, can be reconstructed. The best results are obtained for warm dry and warm humid climates. The composition of heavy-mineral assemblages can only indirectly provide information about a cold climate during deposition, through the reconstruction of aeolian or fluvial processes typical of such a climate.

The composition of the heavy-mineral assemblages is in Poland the main indicator of the boundary between the Neogene and the Quaternary, as well as between the preglacial and glacial Quaternary. Periglacial conditions preceding the advance of the first ice sheet were recorded in the preglacial deposits only as an increase in the content of rounded and frosted quartz grains, while the heavy-mineral composition remained unchanged (Fig. 3, B1b). Heavy-mineral analysis is also very helpful in the interpretation of different depositional environments (aeolian, fluvial, proglacial fluvioglacial, fluvioglacial, and glacial) and in establishing their stratigraphical position.

The results of heavy-mineral analysis can be important for understanding of sedimentary units at a regional or local scale. For example, they make it possible to recognise exaration and to find out source areas, for instance in the form of river catchment areas. Finally, it should be stressed that reliable results can be obtained only if, in addition to heavy-mineral analysis, also other textural features are studied, particularly the grain-size composition, roundness and frosting of quartz grains, and quartz percentage of a sediment.

\section{Acknowledgements}

I wish to thank Dr hab. Małgorzata Roman for providing me with the unpublished data presented in the diagram of the Baruchowo profile and Dr Maria Wilgat for translation of the manuscript.

\section{References}

Barcicki, M., 1997. Ewolucja rzeźby w czwartorzędzie okolic Wierzbicy (północno-wschodnie obrzeżenie Gór Świętokrzyskich) [Development of the relief in the surroundings of Wierzbica (NE margin of the Holy Cross Mountains - central Poland) during the Quaternary]. Prace Instytutu Geografii WSP w Kielcach 2, 1-170. 
Barcicki, M. \& Ciupa, T., 2007. Morfologia i wypełnienie klinów mrozowych $\mathrm{w}$ glinach zwałowych w północno-wschodnim obrzeżeniu Gór Świętokrzyskich [Morphology and infilling of ice wedges in glacial till at the NE border of the Holy Cross Mts.]. [In:] E. Smolska \& D. Giriat (Eds): Rekonstrukcja dynamiki procesów geomorfologicznych - formy, rzeźby i osady [Reconstruction of morphological processes dynamics - landforms and deposits]. University of Warsaw, Warszawa, 43-53.

Barczuk, A. \& Mycielska-Dowgiałło, E., 2001. Znaczenie składu mineralnego dla rozpoznania obecności procesów eolicznych [Interpretation of aeolian processes in the light of sedimentary mineral composition]. [In:] E. Mycielska-Dowgiałło \& J. Rutkowski (Eds): Eolizacja osadów jako wskaźnik stratygraficzny czwartorzędu [Aeolisation of sediments as an indicator of Quaternary stratigraphy]. University of Warsaw, Warszawa, 39-42.

Barczuk, A. \& Nejbert, K., 2007. Analiza minerałów nieprzezroczystych w badaniach skał okruchowych [Opaque mineral analysis in clastic rock research]. [In:] E. Mycielska-Dowgiałło (Ed): Badania cech teksturalnych osadów czwartorzędowych $i$ wybrane metody oznaczania ich wieku [Textural analyses and selected geochronometrical methods in the research of Quaternary deposits]. Uniwersytet Warszawski, Warszawa, 205-228.

Bujak, Ł., 2010. Osady preglacjalne południowej części Niziny Mazowieckiej w świetle wyników analizy minerałów ciężkich [Heavy minerals in preglacial sediments of the southern Mazovian Lowland]. Biuletyn Państwowego Instytutu Geologicznego 438, 19-31.

Cailleux, A., 1942. Les actions éoliennes periglaciaires en Europe. Mémoires de la Société Géologique de France (Nouvelle Série) 46, 1-127.

Chlebowski, R. \& Lindner, L., 1991. Źródła materiału i warunki akumulacji lessów młodszych Wyżyny Małopolskiej [Source areas and depositional conditions of the Younger Loess Unit of the Malopolska Upland]. Biuletyn Geologiczny 32, 15-50.

Chlebowski, R. \& Lindner, L., 2004. Aspekty mineralogiczne w metodyce badań lessów na przykładzie lessów polskich i ukraińskich [Mineralogical issues in the methodology of loess analysis with examples from loesses of Poland and Ukraine]. [In:] A. Kostrzewski (Ed): Geneza, litologia i stratygrafia utworów czwartorzedowych [Genesis, lithology and stratigraphy of Quaternary deposits], 4. Adam Mickiewicz University, Poznań, 17-36.

Cichosz-Kostecka, A., Mycielska-Dowgiałło, E. \& Manikowska, B., 1991. Late Glacial aeolian processes in the light of sediment analysis from Kamion profile near Wyszogród. Zeitschrift für Geomorpholgie, Neue Folge, Supplement Band 90, 45-50.

Czerwonka, J.A. \& Witek, B., 1977. Granulometric and petrographic studies of tills of south-western Poland. Biuletyn Instytutu Geologicznego 305, 45-58.

Dąbski, M., 2001. Significance of heavy mineral analysis in determing the source of mineral material in glacial till. [In:] D.J.A. Evans, J.A. Piotrowski \& C.D. Clark (Eds): Palaeo-ice stream international symposium - Volume of abstracts. Aarhus University, 24.
Derkachev, A.N. \& Nikolaeva, N.A., 2013. Possibilities and restrictions of heavy-mineral analyses for the reconstruction of sedimentary environments and source areas. Geologos 19 (this issue), 147-158.

Derkacz, M., Marcinkowski, B. \& Żarski, M., 2009. Osady lodowcowe na przedpolu Tatr w rejonie Toporowej Cyrhli i na Niżnej Palenicy Pańszczykowej [Glacial deposits in the foreland of the Tatra Mountains near Toporowa Cyrhla and Niżna Palenica Pańszczykowa]. Przeglad Geologiczny 57, 80-84.

Dymowska, T., Dymowski, W., Mityk, J. \& Mycielska-Dowgiałło, E., 1984. Cechy teksturalne osadów wydmowych pustyń Azji Południowo-Zachodniej [Textural properties of dune deposits of the south-western Asian deserts]. Rocznik Polskiego Towarzystwa Geologicznego 54, 241-260.

Dzierwa, K. \& Mycielska-Dowgiałło, E., 2003. Rekonstrukcja dynamiki procesów eolicznych i czasu ich trwania na podstawie wybranych cech teksturalnych osadów wydmy w Cięciwie [Reconstruction of the dynamics of aeolian processes and of their duration on the basis of selected textural features of the deposits within the dune at Cięciwa (eastern Poland)]. Przeglad Geologiczny 51, 163-167.

Florek, W., Florek, E. \& Mycielska-Dowgiałło, E., 1987. Morphogenesis of the Vistula Valley between Kępa Polska and Płock in the Late Glacial and Holocene. [In:] L. Starkel (Ed.): Evolution of the Vistula river valley during the last 15000 years. Part II. Geographical Studies, Special Issue 4, 189-205.

Florek, W. \& Mycielska-Dowgiałło, E., 1991. Structural and textural character of alluvial deposits as an indicator of environmental conditions. [In:] F. Gullentops (Ed.): Wetlands in Flanders. Aardkundige Mededelingen 6, 173-179.

Florek, W., Mycielska-Dowgiałło, E. \& Starkel, L., 1990. Lithology and facies of fluvial deposits. [In:] L. Starkel (Ed.): Evolution of the Vistula River valley during the last 15,000 years. Part III. Geographical Studies, Special Issue 5, 111-126.

Gadomska, S., 1959. Osady czwartorzędowe okolic Garwolina [Quaternary deposits from the surroundings of Garwolin]. Przeglad Geologiczny 7, 555-556.

Giriat, D., 2003. Wptyw stopnia wodnego we Wtocławku na wybrane cechy teksturalne osadów korytowych Wisty [Influence of the Wtoctawek dam on textural features of Vistula channel sediments]. Ph.D. thesis Warsaw University (unpublished).

Goździk, J., 1980. Zastosowanie mikroskopii i graniformametrii do badań osadów kopalni węgla brunatnego "Bełchatów" [The role of micromorphologic analyses in investigations of the deposits in the Bełchatów open-cast mine]. Studia Regionalne 4, 101-114.

Goździk, J. \& Wiatrak, M., 2001. O genezie i wieku utworów czwartorzędowych w profilu wiercenia Lesiów PIG-1 w świetle analizy kształtu ziarn kwarcowych [Genesis and age of the Quaternary deposits of the Leśniów well log]. [In:] E. Mycielska-Dowgiałło (Ed.): Eolizacja osadów jako wskaźnik stratygraficzny czwartorzędu [Aeolisation of sediments as an indicator for their 
Quaternary stratigraphic position]. University of Warsaw, Warszawa, 81-92.

Goździk, J., Kenig, K. \& Skórzak, A., 2010. Zmiany kształtu ziarn kwarcowych oraz składu mineralnego piaszczystych osadów miocenu, pliocenu i niższego czwartorzędu w rowie Kleszczowa [Changes in the shape of quartz grains and in mineral composition of the Miocene, Pliocene and early Quaternary sand deposits in the Kleszczów Graben]. Biuletyn Państwowego Instytutu Geologicznego 438, 33-50.

Jęczmyk, M. \& Kanasiewicz, J., 1970. Minerały ciężkie $\mathrm{w}$ aluwiach górnej Kwisy [Heavy minerals in fluvial deposits of the upper course of the Kwisa river]. Kwartalnik Geologiczny 14, 182-188.

Kamińska, R., Konecka-Betley, K. \& Mycielska-Dowgiałło, E., 1986. The Liszyno dune in the Vistula valley (east of Płock). Biuletyn Peryglacjalny 31, 141-162.

Kenig, K., 1999. Analiza minerałów ciężkich [Heavy-mineral analysis]. [In:] L. Marks \& A. Ber (Eds): Metodyka opracowania Szczegótowej Mapy Geologicznej Polski $w$ skali 1:50,000 [Instruction to the detailed geological map of Poland, 1:50,000]. Państwowy Instytut Geologiczny, Warszawa, 58-60.

Konecka-Betley, K. \& Majsterkiewicz, T., 1973. Geneza gleb wytworzonych z pokrywowych utworów pyłowych Polski środkowej [Genesis of soils developed in silty cover sediments of central Poland]. Roczniki Glebozawcze 24, 133-158.

Korotaj, M. \& Mycielska-Dowgiałło, E., 1982. Würmian periglacial processes in the Kolno Plateau in the light of sedimentologic investigations with the use of scanning electron microscope. Biuletyn Peryglacjalny 29, 53-76.

Kosmowska-Ceranowicz, B., 1966. Osady preglacjalne dorzecza środkowej Wisły [Preglacial deposits of the middle Vistula drainage basin]. Prace Muzeum Ziemi 9, 223-296.

Kosmowska-Ceranowicz, B., 1976. Wiek osadów z Cetynia i Ponurzycy w świetle badań mineralogiczno-petrograficznych [The age of deposits from Ceten and Ponurzyca in the light of mineralogical and petrographic analyses]. Kwartalnik Geologiczny 20, 627-641.

Kosmowska-Ceranowicz, B., 1979. Zmienność litologiczna i pochodzenie okruchowych osadów trzeciorzędowych wybranych rejonów północnej i środkowej Polski w świetle wyników analizy przezroczystych minerałów ciężkich [Lithology and origin of Tertiary clastic deposits in central and northern Poland: results of translucent heavy-mineral analyses]. Prace Muzeum Ziemi 30, 3-73.

Kosmowska-Ceranowicz, B., 1987. Porównanie serii ochoty z osadami preglacjalnymi (plioceńskimi) centralnej Polski [Comparison of the Ochota unit with preglacial (Pliocene) deposits in central Poland]. [In:] A. Jahn \& S. Dyjor (Eds): Problemy młodszego neogenu $i$ eoplejstocenu w Polsce [Problems of the Early Neogene and Eopleistocene]. Ossolineum, Wrocław, 247-254.

Krysowska-Iwaszkiewicz, M., 1974. Studium mineralogiczno-petrograficzne kenozoicznych osadów lądowych Wyżyny Krakowskiej [Mineralogical and petrographical study of Cenozoic continental deposits of the Cracovian upland]. Prace Mineralogiczne PAN 35, 62-64.

Krzyszkowski, D., 1995. An outline of the Pleistocene stratigraphy of the Kleszczów Graben, Bełchatów outcrop, central Poland. Quaternary Sciences Review 14, 61-83.

Krzyszkowski, D., 2010. Stratygrafia, petrografia i paleogeografia glin lodowcowych [Till stratigraphy, petrography and palaeogeography along the northwestern coastal region of Poland]. Biuletyn Państwowego Instytutu Geologicznego 438, 51-91.

Kuźnicki, F., Białousz, S., Rusiecka, D. \& Skłodowski, P., 1974. Charakterystyka procesu bielicowania w glebach wytworzonych z piasków wydmowych Puszczy Kampinowskiej [Characteristics of the podzolization process in soils developed in dune sands in the Puszcza Kampinoska forest]. Rocznik Gleboznawczy 25, 25-51.

Ludwikowska-Kędzia, M., 2000. Ewolucja środkowego odcinka doliny rzeki Belnianki w późnym glacjale i holocenie [Evolution of the middle segment of the Belnianka River valley in the Late Glacial and Holocene]. Dialog Press, Warszawa, $181 \mathrm{pp}$.

Ludwikowska-Kędzia, M., 2013. The composition of transparent heavy minerals in Quaternary sediments of the Kielce-Łagów valley (Holy Cross Mountains, Poland). Geologos 19 (this issue), 95-129.

Łydka, K., 1953. Opracowanie petrograficzne preglacjału rejonu Warszawy [Petrographical study of preglacial deposits in the surroundings of Warsaw]. Instytut Geologiczny, Warszawa, 5 -24.

Łydka, K. \& Turnau-Morawska, M., 1967. Minerały ciężkie $\mathrm{w}$ osadach trzeciorzędowych i plejstoceńskich w Marantowie k. Konina [Heavy minerals in Tertiary and Pleistocene deposits, Marantów site near Konin]. Prace Instytutu Geologicznego 48, 137-144.

Manikowska, B., 1985. O glebach kopalnych, stratygrafii i litologii wydm Polski środkowej [On the palaeosols, stratigraphy and lithology of the dunes in central Poland]. Acta Geographica Lodziensia 52, 1-137.

Marcinkowski, B., 1990. Przeobrażenie ilmenitu i mineralizacji towarzyszącej w piroksenitach masywu Tajno na przykładzie otworu Tajno IG-4 [Processes of ilmenite metamorphosis and accompaying mineralization in pyroxenes in the Tajno massif, with the Tajno IG-4 borehole as an example]. Kwartalnik Geologiczny 34, 571-584.

Marcinkowski, B., 1999. Opracowanie litologiczno-petrograficzne i mineralogiczne do Szczegótowej Mapy Geologicznej Polski 1:50 000. Arkusz Uniejów [Petrographical and mineralogical studies to the Detailed geological map of Poland 1:50,000, sheet Uniejów]. Państwowy Instytut Geologiczny, Warszawa, 3-11.

Marcinkowski, B., 2007. Wykorzystanie składu mineralnego i morfologii ziaren minerałów ciężkich do określania środowiska sedymentacyjnego [The application of the mineral composition and the morphology of mineral grains to the interpretation of the sedimentary environment]. Przeglad Geologiczny 55, 207.

Marcinkowski, B. \& Starnawska, E., 2004a. Zastosowanie mikrosondy EDS do badań mineratów ciężkich przy re- 
alizacji Szczegótowej Mapy Geologicznej Polski 1:50,000 [EDS analysis in heavy-mineral research: application to the Detailed geological map of Poland 1:50,000]. Państwowy Instytut Geologiczny, Warszawa, 6-11.

Marcinkowski, B. \& Starnawska, E., 2004b. Application of EDS microprobe in studies of heavy minerals from Quaternary sediments while constructing Detailed geological map of Poland in scale 1:50 000. [In:] WDS \& Cl (Eds): A workshop focusing on microanalitical techniques in geological applications and material science. Polish Geological Institute, Warszawa, 15-17.

Marcinkowski, B. \& Wiszniewska, J., 2007. Okruchowe nagromadzenia minerałów tytanu w piaszczystych osadach pótnocno-wschodniej Polski [Titanium concentrations within sandy deposits of NE Poland]. Państwowy Instytut Geologiczny, Warszawa, 17-27.

Marcinkowski, B., 2008. Opracowanie litologiczno-petrograficzne i mineralogiczne do Szczegótowej Mapy Geologicznej Polski, 1:50,000. Arkusz Lipica-Sepopol [Petrographical and mineralogical studies to the Detailed geological map of Poland 1:50,000, sheet Lipica-Sepopol]. Państwowy Instytut Geologiczny, Warszawa, 4-21.

Marcinkowski, B., 2009. Opracowania litologiczno-petrograficzne i mineralogiczne do Szczegótowej Mapy Geologicznej Polski, 1:50,000. Arkusz Pionki [Petrographical and mineralogical studies to the Detailed geological map of Poland 1:50,000, sheet Pionki]. Państwowy Instytut Geologiczny, Warszawa, 5-21.

Marcinkowski, B., Winter, H., Wyszomierski, M. \& Żarski, M., 2009. Sytuacja geologiczna osadów interglacjatu mazowieckiego w Przytulinie [Geological characteristics of interglacial deposits in Przytulin]. 16th Conference "Stratygrafia plejstocenu Polski. Zimna Woda" (2009), 189-195.

Morawski, J., 1968. Spostrzeżenia nad odpornością i typem granatów w piaskach różnych środowisk sedymentacyjnych [Types and weathering resistance of garnets from the sands of different sedimentary environments]. Annales Universitatis Marie-Curie Sktodowska 20, 27-54.

Morton, A., Hounslow, M.W. \& Frei, D., 2013. Heavy-mineral, mineral-chemical and zircon-age constraints on the provenance of Triassic sandstones from the Devon coast, southern Britain. Geologos 19 (this issue), 67-85.

Mycielska-Dowgiałło, E., 1977. Channel pattern changes during the Last Glaciation and Holocene in the northern part of the Sandomierz Basin. [In:] J.K. Gregory (Ed.): River channel changes. Wiley-Interscience, 75-87.

Mycielska-Dowgiałło, E., 1978. Rozwój rzeźby fluwialnej północnej części Kotliny Sandomierskiej w świetle badań sedymentologicznych [Development of the fluvial morphology in the northern part of the Sandomierz Basin]. Rozprawy Uniwersytetu Warszawskiego 120, 1-168.

Mycielska-Dowgiałło, E., 1980. Cechy strukturalne i teksturalne osadów budujących formy eoliczne w rejonie Palmyry [Structural and textural features in deposits of aeolian forms in the Palmyra region]. Prace $i$ Studia Geograficzne 2, 189-219.

Mycielska-Dowgiałło, E. (Ed.), 1988. Geneza osadów i gleb $w$ świetle badań w mikroskopie elektronowym [Genesis of deposits and soils on the basis of SEM analysis]. Warsaw University Press, Warszawa, 227 pp.

Mycielska-Dowgiałło, E., 1992. Desertification on the basis of sedimentological features of dune deposits. Geographica Polonica 60, 181-195.

Mycielska-Dowgiałło, E., 1993. Estimates of Late Glacial and Holocene aeolian activity in Belgium, Poland and Sweden. Boreas 22, 165-170.

Mycielska-Dowgiałło, E., 1995. Wybrane cechy teksturalne osadów [Some textural features of deposits and their significance for interpretations]. [In:] E. Mycielska-Dowgiałło \& J. Rutkowski (Eds): Badania osadów czwartorzędowych. Wybrane metody i interpretacja wyników [Investigations of Quaternary sediments. Some methods and interpretation of the results]. University of Warsaw, Warszawa, 29-105.

Mycielska-Dowgiałło, E., 1996. Analiza sedymentologiczna piaszczystych osadów eolicznych i jej znaczenie dla określenia długości trwania procesów pustynnienia [Sedimentological analysis of aeolian sands and assessment of the timespan involved in desertfication]. Rocznik Świętokrzyski B23, 109-116.

Mycielska-Dowgiałło, E. (Ed.), 2001. Eolizacja osadów jako wskaźnik stratygraficzny czwartorzędu [Aeolisation of sediments as an indicator for determining a Quaternary stratigraphic position]. University of Warsaw, Warszawa, $141 \mathrm{pp}$.

Mycielska-Dowgiałło, E., 2007. Metody badań cech teksturalnych osadów klastycznych i wartość interpretacyjna wyników [Research methods for textural features of clastic deposits and the significance of the results for interpretations]. [In:] E. MycielskaDowgiałło \& J. Rutkowski (Eds): Badania cech teksturalnych osadów czwartorzędowych $i$ wybrane metody oznaczania ich wieku [Research into the textural features of Quaternary sediments and some dating methods]. SWPR, Warsaw, 95-180.

Mycielska-Dowgiałło, E. \& Cichosz-Kostecka, A., 1987. Cechy teksturalne osadów aluwialnych Brenty (północne Włochy) [Textural features of the Brenta fluvial deposits (N Italy)]. Sprawozdania z Badań Naukowych 7, 91-93.

Mycielska-Dowgiałło, E., Cichosz-Kostecka, A., Florek, W. \& Jatczak, D., 1990. Morphodynamic processes in the light of an analysis of different age alluvial deposits in the Vistula valley near Płock. Miscellanea Geographica 4, 37-47.

Mycielska-Dowgiałło, E. \& Ludwikowska-Kędzia, M., 2011. Alternative interpretation of grain-size data from Quaternary deposits. Geologos 17, 189-203.

Mycielska-Dowgiałło, E. \& Woronko, B., 2001. Wybrane cechy sedymentologiczne osadów ułatwiające ich podział stratygraficzny, na przykładzie otworów Galumin 1, Kozły K-1, Niksowizna i Olszewo Węgorzewskie [The role of some sedimentological features in stratigraphic interpretations. Case study of the Galumin 1, Kozły K-1, Niksowizna and Olszewo Węgorzewskie well logs]. [In:] E. MycielskaDowgiałło (Ed.): Eolizacja osadów jako wskaźnik stratygraficzny czwartorzędu [Aeolisation of sediments as 
an indicator for Quaternary stratigraphy]. Warszawa, 43-58.

Mycielska-Dowgiałło, E. \& Woronko, B., 2004. The degree of aeolization of Quaternary deposits in Poland as a tool for stratigraphic interpretation. Sedimentary Geology 168, 149-163.

Racinowski, R., 1974. Dynamika środowiska sedymentacyjnego strefy brzegowej Pomorza Zachodniego w świetle badań minerałów ciężkich i uziarnienia osadów [Dynamics of the seashore sedimentary environment: a record in heavy-mineral and grain-size data]. Prace Naukowe Politechniki Szczecinskiej, Instytut Inżynierii Wodnej 4, 1-156.

Racinowski, R., 1992. Charakterystyka standardowych cech litologicznych rumowiska strefy brzegowej morza Pobrzeża Szczecińskiego [Standard lithological features of seashore sediments of the Szczecin Baltic coast]. [In:] Badania strefy brzegowej Bałtyku [Research of the Baltic coast]. Prace Naukowe Politechniki Szczecińskiej, Politechnika Szczecińska 459(2), 5-93.

Racinowski, R., 1995. Analiza minerałów ciężkich w badaniach osadów czwartorzędowych Polski [Heavy mineral analysis as a tool of Quaternary studies in Poland]. [In:] E. Mycielska-Dowgiałło \& J. Rutkowski (Eds): Badania osadów czwartorzędowych. Wybrane metody i interpretacja wyników [Research of Quaternary sediments. Some methods and interpretation of the results]. University of Warsaw, Warszawa, 151-166.

Racinowski, R., 2002. Badania minerałów ciężkich osadów pyłowych Naddniestrza halickiego [Heavy minerals of loess deposits in the Halyč Prydniestrov'ja region]. Studia Geologica Polonica 119, 219-236.

Racinowski, R., 2010. Główne przezroczyste minerały ciężkie w osadach czwartorzędowych Polski [Main transparent heavy minerals in Quaternary deposits]. Biuletyn Państwowego Instytutu Geologicznego 438, 99105.

Racinowski, R., \& Rzechowski, J., 1969. Minerały ciężkie w glinach zwałowych Polski środkowej [Heavy minerals in boulder clays of central Poland]. Kwartalnik Geologiczny 13, 479-490.

Rizzetto, F., Mycielska-Dowgiałło, E. \& Castiglioni, G.B., 1998. Some aeolian features in the Po plain near Este (North Italy). Geografia Fisica e Dinamica Quaternaria 21, 245-253.

Roman, M., 2010. Preglacjalne osady rzeczne ze stanowiska Baruchowo (Kotlina Płocka) [Preglacial fluvial deposits from the Baruchowo site (Płock Basin)]. Państwowy Instytut Geologiczny 438, 107-121.

Rzechowski, J., Gronkowska, B., Kenig, K. \& Sobczyk, B., 1975. Studium porównawcze współczesnych i kopalnych osadów rzecznych [Present and fossil fluvial deposits: a comparative study]. Unpublished report, Instytut Geologiczny, Warszawa, 46-53.

Sarnacka, Z. \& Krysowska-Iwaszkiewicz, M., 1974. Osady eoplejstoceńskie okolic Magnuszewa na południowym Mazowszu [Eopleistocene sediments of the
Magnuszew area]. Biuletyn Instytutu Geologicznego. Z badań czwartorzędu Polski 268, 165-188.

Urbaniak-Biernacka, U., 1975. Wydmy okolic Świętouścia na wyspie Wolin [The dunes in the Świętouść region on Wolin Island]. Acta Universitatis Nicolai Copernici, Geografia 11, 57-85.

Van Loon, A.J., 1972/1973. "Habitus" of some heavy minerals from the Tertiary of Southern Limburg (The Netherlands). Mededelingen van de Rijks Geologische Dienst, Nieuwe Serie 23, 39-67.

Van Loon, A.J., 2009b. Soft-sediment deformation structures in siliciclastic sediments: an overview. Geologos 15, 3-55.

Vieira, G.T., Mycielska-Dowgiałło, E. \& Woronko, B., 2003. Sedimentological analysis of sandy-gravel accumulations, Serra da Estrela plateau (Portugal). Landform Analysis 4, 99-107.

Wachecka-Kotkowska, L. \& Ludwikowska-Kędzia, M., 2013. Heavy-mineral assemblages from fluvial Pleniglacial deposits of the Piotrków Plateau and the Holy Cross Mountains - a comparative study. Geologos 19 (this issue), 131-146.

Wajda, W., 1970. Minerały ciężkie piasków dennych polskiego Wybrzeża Bałtyku [Heavy minerals of the bottom sands, Polish Baltic coast]. Rocznik Polskiego Towarzystwa Geologicznego 40, 131-146.

Weckwerth, P. \& Chabowski, M., 2013. Heavy minerals as a tool to reconstruct river activity during the Weichselian glaciation (Torun Basin, Poland). Geologos 19 (this issue), 25-46.

Woronko, B., 2001. Stopień eolizacji osadów czwartorzędowych na stanowisku Dębe k. Warszawy [Aeolisation degree of Quaternary deposits at the Dębe site near Warsaw]. [In:] E. Mycielska-Dowgiałło (Ed.): Eolizacja osadów jako wskaźnik stratygraficzny czwartorzędu [Aeolisation of sediments as an indicator of Quaternary stratigraphy]. University of Warsaw, Warszawa, 59-64.

Woronko, B., 2012a. Zapis procesów eolicznych w osadach piaszczystych plejstocenu na wybranych obszarach Polski środkowej i północno-wschodniej [Records of aeolian processes in the Pleistocene sandy sediments in some areas of central and north-eastern Poland]. Warsaw University, Warszawa, $134 \mathrm{pp}$.

Woronko, B. (Ed.), 2012b. Grain-size analysis: methods and significance. Geologos 14(4), 187-238.

Woronko, B., Rychel, J., Karasiewicz, M.T., Ber, A., Krzywicki, T., Marks, L. \& Pochocka-Szwarc, K., 2013. Heavy and light minerals as a tool for reconstruction of depositional environments: an example from the Jałówka site (northern Podlasie region, NE Poland). Geologos 19 (this issue), 47-66.

Manuscript received: 28 November 2012 Revision accepted: 1 March 2013 